\title{
THE EFFECTIVENESS OF LEARNING DEVICES OF EARTH AND SPACE PHYSICS ORIENTED INQUIRY MODELS TO IMPROVE CRITICAL THINKING SKILL OF STUDENTS
}

\author{
Dina Syaflita ${ }^{* 1)}$, Muhammad Nor ${ }^{2)}$ \\ ${ }^{1,2)}$ Physics Education, University of Riau \\ e-mail: dinasyaflita@yahoo.com \\ mnoer_rs@yahoo.com
}

\begin{abstract}
Physics of earth and space is one of the subject that learn about natural phenomena. Leraning activity that learn about nature require students to be able to think logically and critically about a phenomena. Therefore, learning models and learning tools are needed that support lecture activity that allow students to construct knowledge through experiments and gather various information. The fact found that the lectures of earth and space physics that are used today are still conventional. This does not support the improvement of student's critical thinking skill. One solution that can be done is to develop lecture devices consisting of worksheets oriented to inquiry models and earth teaching aids which are implemented in lectures. The aim of this research is to obtain the effectivity value of the devices of earth and space physics lecture to improve the critical thinking skill of students. Data collection instrument is pretest and posttest before and after use the product. Data analysis technique use t-test correlates with product moment. The result of this research is the worksheet of earth and space physics oriented inquiry model is effective improve of student's critical thinking skill with the value of the product moment is $60 \%$.
\end{abstract}

Keywords: effectivity, inquiry model, lecture devices

\section{EFEKTIVITAS PERANGKAT PERKULIAHAN FISIKA BUMI DAN ANTARIKSA BERORIENTASI MODEL INKUIRI UNTUK MENINGKATKAN KEMAMPUAN BERPIKIR KRITIS MAHASISWA}

\author{
Dina Syaflita ${ }^{* 1)}$, Muhammad Nor ${ }^{2)}$ \\ ${ }^{1,2)}$ Pendidikan Fisika, Universitas Riau
}

\begin{abstract}
Abstrak
Fisika Bumi dan Antariksa merupakan salah satu mata kuliah yang mengkaji fenomena alam. Kegiatan perkuliahan yang mengkaji tentang alam menuntut siswa untuk mampu berpikir secara logis dan kritis mengenai suatu fenomena. Untuk itu, diperlukan model pembelajaran dan perangkat pembelajaran yang mendukung kegiatan perkuliahan yang memungkinkan mahasiswa mengkonstruksi pengetahuan melalui kegiatan percobaan dan mengumpulkan berbagai informasi. Kenyataan yang ditemukan menunjukkan bahwa perkuliahan fisika bumi dan antariksa yang digunakan saat ini masih konvensional. Hal ini tentu saja tidak mendukung peningkatan kemampuan berpikir kritis mahasiswa. Salah satu solusi yang dapat dilakukan adalah dengan mengembangkan perangkat perkuliahan yang terdiri dari LKM berorientasi model inkuiri dan alat peraga fisika bumi dan antariksa yang kemudian diimplementasikan dalam kegiatan pembelajaran. Tujuan penelitian ini adalah untuk mendapatkan nilai efektivitas perangkat perkuliahan fisika bumi dan antariksa dalam meningkatkan kemampuan berpikir kritis mahasiswa. Instrumen pengumpulan data dalam
\end{abstract}


penelitian ini menggunakan nilai pretes dan postes mahasiswa sebelum dan sesudah penggunaan produk. Teknik analisis data menggunakan uji-t berkorelasi produk moment. Hasil penelitian yaitu berupa perangkat LKM fisika bumi dan antariksa berorientasi model inkuiri, efektif meningkatkan kemampuan berpikir mahasiswa dengan nilai produk moment sebesar $60 \%$.

Kata kunci: efektivitas, model inkuiri, perangkat perkuliahan

\section{Pendahuluan}

Kegiatan perkuliahan yang mempelajari tentang alam menuntut siswa untuk mampu berpikir secara logis dan kritis mengenai suatu fenomena alam. Kemampuan berpikir kritis ini sangat diperlukan oleh siswa untuk dapat menyaring informasi, mempertanyakan suatu kebenaran ilmu, dan segala hal dalam kehidupan mereka yang menuntut mereka untuk berpikir secara logis, kirits, dan sistematis (Syahbana, 2012). Perkuliahan Fisika sebagai salah satu perkuliahan yang mempelajari gejala-gejala alam juga membutuhkan kemampuan berpikir kritis untuk dapat memahami, mengkritisi suatu kebenaran, dan memecahkan masalah-masalah yang berhubungan dengan alam.

Pengembangan keterampilan berpikir kritis sangat dibutuhkan oleh siswa terutama mahasiswa calon guru Fisika, khususnya dalam perkuliahan Sistematika Fisika tentang konsep ilmu pengetahuan alam dan antariksa. Hal ini disebabkan karena pembelajaran fisika bumi dan antariksa di sekolah-sekolah dan di perguruan tinggi belum didukung dengan kegiatan praktikum (Pujani \& Liliasari, 2011).

Jacqueline dan Brooks dalam (Santrock, 2007) menyatakan bahwa banyak sekali sekolah tidak mengembangkan kemampuan berpikir kirtis siswa. Sering kali guru meminta siswa untuk menceritakan kembali, menjelaskan, mendefinisikan, mendeskripsikan, dan menganalisis suatu topik pembelajaran. Hal ini tidak mendorong siswa untuk memunculkan ide-ide baru buah pikirannya sendiri dan memikirkan ulang mengenai suatu kesimpulan. Permintaan guru yang demikian cenderung menuntut siswa untuk memberikan jawaban yang benar. Akibatnya, siswa mengalami pendangkalan berpikir dan tidak mampu untuk berpikir secara mendalam dan kritis tentang suatu fenomena.

Mengacu kepada kurikulum yang menitikberatkan pada kemampuan berpikir, ada 12 indikator keterampilan berpikir kritis yang dikelompokkan dalam lima kelompok keterampilan berpikir. Adapun kelima indikator berpikir kritis tersebut adalah: 1) memfokuskan pertanyaan, 2) menganalisis argumen, 3) bertanya dan menjawab pertanyaan tentang suatu penjelasan dan tantangan, 4) mempertimbangkan kredibilitas suatu sumber, 5) mengobservasi dan mempertimbangkan hasil observasi (Rahma, 2012).

Pembelajaran Fisika di suatu sekolah lanjutan atau di suatu perguruan tinggi yang masih mengunakan metode konvensional kurang tepat untuk mengimbangi perkembangan IPTEK yang begitu pesat. Pembelajaran fisika hendaknya selalu megutamakan keterampilan proses agar dapat terwujud kemampuan pemecahan masalah, sehingga mahasiswa dapat menguasai konsep fisika dengan baik dan berprestasi secara optimal. Untuk itu, diperlukan adanya penggunaan bahan ajar dan media pembelajaran yang sesuai dengan materi pelajaran.

Perkuliahan Fisika Bumi dan Antariksa dilengkapi dengan LKM. LKM merupakan salah satu bahan ajar yang lebih menfokuskan pada pelaksanaan kegiatan tertentu dalam pembelajaran. LKM memiliki tujuan-tujuan seperti yang dikemukakan Prastowo (2011) sebagai berikut: 1) menyajikan bahan ajar yang memudahkan siswa untuk berinteraksi dengan materi yang diberikan; 2) menyajikan tugastugas yang meningkatkan penguasaan siswa terhadap materi yang diberikan, 3) melatih kemandirian belajar siswa.

Selain penggunaan LKM, kegiatan perkuliahan juga membutuhkaan media pembelajaran yang sesuai dengan karakteristik materi. Media merupakan suatu saluran komunikasi dari pemberi informasi kepada penerima informasi, dimana informasi tersebut dapat dilihat secara terbatas atau luas. Media dapat berupa manusia, materi, kejadian yang membangun suatu kondisi yang membuat 
siswa mampu memahami pengetahuan, keterampilan, atau sikap. Jadi, adanya penggunaan LKM dan media dalam pembelajaran Fisika Bumi dan Antariksa secara teori dapat meningkatkan pemahaman materi dan kemampuan berpikir siswa.

Suatu produk yang baik harus dapat membantu siswa mencapai sasaran setelah melalui uji efektivitas. Uji efektivitas bertujuan untuk melihat seberapa efektif produk yang sedang dikembangan digunakan dalam pembelajaran. Uji efektivitas terhadap suatu produk yang dikembangkan dapat dilakukan melalui pretes dan postes terhadap penguasaan suatu materi. Uji-t digunakan untuk melihat sejauh mana keefektivan bahan ajar yang dikembangkan tersebut (Emzir, 2012).

Pendekatan pembelajaran yang dapat memberikan bekal bagi mahasiswa untuk dapat memahami dan mengaplikasikan konsep-konsep dasar fisika serta menunjang peningkatan berfikir kritis salah satunya adalah melalui model inkuiri. Model pembelajaran inkuiri terbimbing dengan kegiatan laboratorium adalah suatu model pembelajaran yang esensinya untuk melibatkan mahasiswa kedalam suatu masalah yang sesungguhnya dengan cara menkonfrontasikan mereka ke dalam suatu area penyelidikan, membantu mahasiswa mengidentifikasi masalah secara konseptual dan metodologis (Indrawati, 2000). Peningkatan kemampuan berpikir kritis mahasiswa semakin baik dengan bantuan media pembelajaran dan LKM berorientasi model inkuiri.

Pembelajaran inkuiri memberikan kesempatan kepada mahasiswa untuk mengkonstruksi pengetahuan sendiri, menggali konsep, mengambil inisiatif suatu tindakan untuk memecahkan masalah, dan melatih kemampuan berpikir kritis mahasiswa dalam memecahkan permasalahan fisika (Puspita \& Jatmika, 2013). Pembelajaran inkuiri memungkinkan mahasiswa berperan sebagai pebelajar yang secara aktif menemukan atau membuktikan suatu pengetahuan melalui proses penyelidikan dan memecahkan masalah (Kurniawati, et al., 2014). Dengan demikian, model inkuiri dapat digunakan dalam perkuliahan IPBA untuk meningkatkan kemampuan berpikir kritis mahasiswa.

Model inkuiri terdiri atas tiga jenis, yaitu: model inkuiri terstruktur, model inkuiri terbimbing, dan model inkuiri bebas. Model inkuiri terstruktur ditunjukkan dengan siswa mengikuti arahan guru dalam melakukan penyelidikan dan guru membimbing siswa menganalisis data yang diperoleh. Model inkuiri terbimbing memberikan keleluasaan kepada siswa dalam melakukan penyelidikan dan menganalisis data. Guru membimbing siswa melakukan kegiatan dengan memberi pertanyaan awal dan mengarahkan kepada suatu diskusi. Pada model inkuiri bebas, siswa diberi kebebasan lebih luas dalam proses menyelidiki. Siswa mengajukan pertanyaan, hipotesis, prosedur, menarik kesimpulan, dan membuat laporan. Guru menentukan tujuan pembelajaran dan membimbing siswa melakukan analisis hanya jika diperlukan (Purwasih, 2015).

Model inkuiri terbimbing menekankan pada cara berpikir kiritis dan analisis dalam mencari jawaban suatu permasalahan (Sanjaya, 2006). Inkuiri terbimbing mampu meningkatkan keinginan dan motivasi siswa untuk mempelajari suatu konsep (Kurniawati, et al., 2014). Model inkuiri terbimbing memungkinkan siswa berperan aktif dalam suatu proses penyelidikan dalam menemukan suatu pengetahuan. Guru tidak memberikan siswa konsep tetapi membantu siswa melakukan penyeledikan untuk menemukan konsep sendiri (Puspita \& Jatmiko, 2013). Pada model inkuiri, guru hanya bertindak sebagai organisator, fasilitator, dan motivator.

Sebagaimana halnya sebuah model pembelajaran, model inkuiri terdiri dari enam tahapan, yaitu: 1) Orientasi, pada tahap ini guru mengkondisikan iklim pembelajaran yang kondusif, menjelaskan tujuan, dan pokokpokok kegiatan pembelajaran; 2) Perumusan masalah, pada inkuiri terbimbing persoalan ditentukan oleh tenaga pengajar, perlu diperhatikan bahwa persoalan itu real, dapat dikerjakan oleh mahasiswa, dan sesuai dengan kemampuan mahasiswa, sehingga mahasiswa didorong untuk mencari jawaban yang tepat; 3 ) Merumuskan hipotesis, dalam hal ini mahasiswa merumuskan jawaban sementara dan dapat merumuskan berbagai perkiraan kemungkinan jawaban dari suatu permasalahan yang dikaji; 4) mengumpulkan data, mencari dan mengumpul kan data sebanyak-banyaknya bertujuan untuk membuktikan apakah hipotesis mereka benar atau tidak; 5) menganalisis data, data yang sudah dikumpulkan harus dianalisis untuk dapat 
membuktikan hipotesis apakah benar atau tidak, dan 6) menyimpulkan, mendeskripsikan temuan yang diperoleh berdasarkan hasil pengujian hipotesis (Sanjaya, 2006).

Kenyataan yang ditemukan di lapangan menunjukkan bahwa pembelajaran yang digunakan saat ini masih konvensional. Pembelajaran sains di sekolah umumnya bersifat teoritis, melalui ceramah, diskusi, dan penyelesaian soal, tanpa eksperimen ataupun demonstrasi. Hal ini kurang mendukung peningkatan kemampuan berpikir kritis mahasiswa.

Hampir tidak ada kegiatan penyelidikan atau praktikum yang dilakukan untuk mata pelajaran bumi dan antariksa. Pembelajaran selama bab tersebut dilakukan melalui teacher centered yaitu melalui metode ceramah. Semestinya, materi bumi dan antariksa seperti halnya materi fisika yang lain harusnya dipelajari melalui tahapan penyelidikan dan saintifik. Materi bumi dan antariksa tidak ubahnya dengan materi fisika yang lain yang mempelajari fakta melalui fenomena alam. Hanya saja, kegiatan penyelidikan untuk materi bumi dan antariksa membutuhkan alat peraga yang dapat menggambarkan bentuk suatu benda alam dan menunjukkan cara kerjanya.

Penggunaan LKM berorientasi model inkuiri memungkinkan mahasiswa untuk menemukan sendiri dan menguji konsep yang telah diperolehnya. Hal ini dapat mendukung kemampuan berpikir kritis mahasiswa. Oleh karena itu, perlu dikembangkan program perkuliahan Fisika bumi dan antariksa berorientasi model inkuiri untuk meningkatkan kemampuan berpikir kritis mahasiswa. Adapun tujuannya adalah untuk menganalisis efektivitas penggunaan program yang dikembangkan terhadap kemampuan berpikir kritis maha-siswa.

\section{Bahan dan Metode}

Subjek dalam penelitian ini adalah mahasiswa Program Studi Pendidikan Fisika Universitas Riau. Mahasiswa yang dilibatkan adalah mahasiswa semester $\mathrm{V}$ yang mengambil mata kuliah Fisika Bumi dan Antariksa. Pemilihan ini dilakukan dengan asumsi bahwa mahasiswa memiliki pengalaman perkuliahan yang sama.

Pengujian kemampuan berpikir kritis mahasiswa digunakan untuk menentukan nilai efektivitas produk. Jenis data yang diperoleh adalah data primer. Instrumen penilaian yang digunakan adalah soal pretes postes tentang keilmuan Fisika Bumi dan Antariksa yang disesuaikan dengan indikator berpikir kritis. Teknik analisis data menggunakan analisis uji$\mathrm{t}$ berkorelasi dengan persamaan:

$$
t=\frac{\overline{X_{1}}-\overline{X_{2}}}{\sqrt{\frac{S_{1}^{2}}{n_{1}}+\frac{S_{2}^{2}}{n_{2}}-2 r\left(\frac{S_{1}}{\sqrt{n_{1}}}\right)\left(\frac{S_{2}}{\sqrt{n_{2}}}\right)}}
$$

Keterangan:

$$
\begin{aligned}
& \overline{\mathrm{X}_{1}}=\text { Rata-rata pretes } \\
& \overline{\mathrm{X}_{2}}=\text { Rata-rata postes } \\
& \mathrm{S}_{1}=\text { Simpangan baku pretes } \\
& \mathrm{S}_{2}=\text { Simpangan baku postes } \\
& \mathrm{S}_{1}^{2}=\text { Varians nilai pretes } \\
& \mathrm{S}_{2}^{2}=\text { Varians nilai postes } \\
& \mathrm{r}=\text { Korelasi antara pretes dan postes }
\end{aligned}
$$

Nilai $r$ pada persamaan (1) merupakan koefisien korelasi nilai pretes dan postes mahasiswa yang didapat dari rumus korelasi product moment, yaitu:

$$
r_{x y}=\frac{A\left(\sum X Y\right)-\left(\sum X\right)\left(\sum Y\right)}{\left(N\left(\sum X^{2}\right)-\left(\sum X\right)^{2}\right)\left(N\left(\sum Y^{2}\right)-\left(\sum Y\right)^{2}\right)}
$$

$$
\begin{aligned}
& \text { Keterangan: } \\
& \mathrm{X}=\text { Rata-rata pretes } \\
& \mathrm{Y}=\text { Rata-rata postes } \\
& r_{x y}=\text { Koefisien korelasi nilai } \\
& \text { pretes dan postes }
\end{aligned}
$$

Harga $t_{\text {hitung }}$ diperoleh dengan mensubtitusikan nilai $r$ pada persamaan 2 ke dalam persamaan 1. Harga $t_{\text {hitung }}$ kemudian dibandingkan dengan $\mathrm{t}_{\text {tabel }}$ dengan menggunakan taraf signifikansi $5 \%$. Pengujian menggunakan t-test berkorelasi uji pihak kanan. Produk yang dikembangkan dikatakan efektif meningkatkan kemampuan berpikir kritis apabila $t_{\text {hitung }}$ kecil dari $t_{\text {tabel }}$. 


\section{Hasil dan Pembahasan}

Hasil kajian ini memberikan gambaran signifikansi produk yang dikembangkan terhadap kemampuan berpikir kritis mahasiswa. Data hasil pretes dan postes mahasiswa diperlihatkan melalui Tabel 1.

Tabel 1. Data perhitungan pretes dan postes struktur Bumi

\begin{tabular}{lrr}
\hline \multicolumn{1}{c}{ Statistik } & Pretes & \multicolumn{1}{c}{ Postes } \\
\hline Rata-rata & 29,72 & 62,72 \\
Standar Deviasi & 9,98 & 7,83 \\
Varians & 99,68 & 61,25 \\
Nilai Terendah & 17,00 & 58,00 \\
Nilai Tertinggi & 41,30 & 74,00 \\
\hline
\end{tabular}

Berdasarkan data Tabel 1 dapat dijelaskan bahwa nilai yang diperoleh siswa bervariasi dengan rentangan nilai 41,30 dan 74,00 . Data deskriptif dari pretes dan postes digunakan untuk menghitung korelasi yang berguna untuk membuktikan signifikansi perbedaan antara hasil belajar sebelum dan sesudah perlakuan. Berdasarkan analisis yang dilakukan dengan menghitung menggunakan persamaan product moment didapat nilai koefisien korelasi (r) sebesar 0,6.

Harga $t_{\text {hitung }}$ didapat dengan mengguna kan rumus t-test berkorelasi sehingga didapat hasil sebesar -5,82. Harga $t_{\text {tabel }}$ didapatkan dengan mencari derajat kebebasan terlebih dahulu. Harga derajat kebebasan didapatkan dari jumlah siswa dikurangi satu. Derajat kebebasannya adalah 4. Derajat kebebasan $(\mathrm{dk})=4$, dan harga kritik "t" pada taraf signifikansi $5 \%$ adalah 2,13, sehingga diperoleh $t_{\text {tabel }}=2,13$. Nilai $t_{\text {hitung }}$ pada penelitian lebih kecil daripada $t_{\text {tabel }}$. Ini menunjukkan bahwa terjadi peningkatan kemampuan berpikir kritis mahasiswa secara signifikan setelah diterapkan LKM fisika bumi dan antariksa berorientasi model inkuiri dalam pembelajaran.

Nilai koefisien korelasi product moment 0,6 artinya terjadi peningkatan kemampuan berpikir kirits mahasiswa menggunakan perangkat perkuliahan yang dikembangkan. Peningkatan kemampuan berpikir kritis ini $60 \%$ disebabkan oleh adanya pemakaian perangkat perkuliahan Fisika Bumi dan Antariksa berorientasi model inkuiri dalam perkuliahan. Perangkat Fisika Bumi dan Antariksa berorientasi model inkuiri dapat meningkatkan kemampuan berpikir kritis mahasiswa dimana secara statistik menggunakan persamaan korelasi product moment menunjukkan bahwa $60 \%$ peningkatan tersebut disebabkan oleh pemakaian perangkat perkuliahan Fisika Bumi dan Antariksa berorientasi model inkuiri dalam perkuliahan. Hal ini sejalan dengan hasil penelitian yang dilakukan oleh Anggareni, et al., (2013) dimana terdapat perbedaan kemampuan berpikir kiritis dan pemahaman konsep antara kelompok siswa yang menggunakan pembelajaran inkuiri dengan pembelajaran secara langsung. Dewi, et al., (2013) dalam penelitiannya tentang pengaruh model pembelajaran inkuiri terbimbing terhadap sikap ilmiah dan hasil belajar IPA mengemukakan bahwa terdapat perbedaan hasil belajar antara siswa yang belajar menggunakan model inkuiri dengan siswa yang menggunakan model pembelajaran konvensional. Kurniawati, Wartono, dan Diantoro (2014) dalam penelitiannya tentang implementasi model inkuri terhadap penguasaan konsep dan kemampuan berpikir kritis memberikan hasil yaitu siswa yang belajar menggunakan model pembelajaran inkuiri memiliki penguasaan konsep dan kemampuan berpikir kritis lebih baik dibandingkan yang menggunakan model pembelajaran konvensional.

Tahapan model inkuiri memungkinkan siswa untuk menggunakan kemampuan berpikir dengan mengkonstruksi sendiri konsep yang dipelajari melalui percobaanpercobaan atau teknik pengumpulan informasi yang lain. Tahapan tersebut terdapat pada langkah-langkah kegiatan yang ada pada LKM. Menurut Asmawati (2015), LKS dan model pembelajaran inquiri terbimbing sangat membantu dalam peningkatan keterampilan berpikir kritis dan penguasaan konsep fisika siswa.

\section{Kesimpulan dan Saran}

Hasil penelitian menunjukkan bahwa terdapat peningkatan kemampuan berpikir kritis mahasiswa yang disebabkan oleh penggunaan LKM fisika bumi dan antariksa berorientasi model inkuiri dalam perkuliahan. 
Model inkuiri yang terdapat dalam langkahlangkah kegiatan pada LKM memungkinkan mahasiswa untuk berpikir secara logis, analisis, dan sistematis dalam mengkonstruksi pengetahuan. Melalui uji statistik berkorelasi diperoleh bahwa perangkat perkuliahan Fisika Bumi dan Antariksa yang dikembangkan efektif meningkatkan kemampuan bepikir kritis mahasiswa.

Perangkat yang dikembangkan dapat digunakan dalam perkuliahan untuk meningkatkan pemahaman konsep dan kemampuan berpikir kritis mahasiswa. Penggunaan LKM yang dikembangkan harus disertai dengan alat peraga maupun prototipe yang sesuai.

\section{Daftar Pustaka}

Anggareni, N. W., N. P. Ristiati, \& L. P. M. Widiyanti, 2013. Implementasi Strategi Pembelajaran Inkuiri terhadap Kemampuan Berpikir Kritis dan Pemahaman Konsep IPA Siswa SMP: $e$ Journal Program Pascasarjana Universitas Pendidikan Ganesha. Vol. 3.

Asmawati, E. Y., 2015. Lembar Kerja Siswa (LKS) Menggunakan Model Guided Inquiry untuk Meningkatkan Keterampilan Berpikir Kritis dan Penguasaan Konsep Siswa: Jurnal Pendidikan Fisika, 3 (1) 1-16.

Dewi, N. L., Dantes, N., \& Sadia, I. W., 2013. Pengaruh model pembelajaran inkuiri terbimbing terhadap sikap ilmiah dan hasil belajar IPA. PENDASI: Jurnal Pendidikan Dasar Indonesia, 3 (1).

Emzir, 2012. Metodologi Penelitian Pendidikan. Raja Grafindo Persada, Jakarta.

Indrawati, 2000. Model-model Pembelajaran $I P A$. Pusat Pengembangan Penataran Guru IPA, Bandung.

Kurniawati, I. D., Wartono, \& M. Diantoro, 2014. Pengaruh Pembelajaran Inkuiri Terbimbing Integrasi Peer Instruction terhadap Penguasaan Konsep dan Kemampuan Berpikir Kritis Siswa. Jurnal Pendidikan Fisika Indonesia, 10 36-46, DOI: 10.15294/jpfi.v10i1.3049.
Liliasari, 1997. Pengembangan Model Pembelajaran Materi Subjek untuk Meningkatkan Keterampilan Berpikir Konseptual Tinggi Mahasiswa Calon Guru IPA. Laporan Penelitian, FPMIPA IKIP Bandung, Bandung.

Prastowo, Andi, 2011. Panduan Kreatif Membuat Bahan Ajar Inovatif. Diva Press, Yogyakarta.

Pujani, N. M., \& Liliasari, 2011. Deskripsi Hasil Analisis Pembelajaran IPBA sebagai Dasar Pengembangan Kegiatan Laboratorium Bagi Calon Guru. Makalah pada Seminar Nasional Pendidikan. FKIP Unila, Bandar Lampung. 29-30 Januari 2011.

Purwasih, R., 2015. Peningkatan Kemampuan Pemahaman Matematis dan Self Confidence Siswa MTS di Kota Cimahi Melalui Model Pembelajaran Inkuiri Terbimbing. Didaktik, 9 (1) 16-25.

Puspita, Asri Trisna, \& Budi Jatmiko, 2013. Implementasi Model Pembelajaran Inkuiri Terbimbing (Guided Inquiry) terhadap Keterampilan Berpikir Kritis Siswa pada Pembelajaran Fisika Materi Fluida Statis Kelas XI di SMA Negeri 2 Sidoarjo. Jurnal Inovasi Pendidikan Fisika , 02 (03) 121-125.

Rahma, A. N., 2012. Pengembangan Perangkat Pembelajaran Model Inkuiri Berpendekatan SETS Materi Kelarutan dan Hasilkali Kelarutan untuk Menumbuhkan Keterampilan Berpikir Kritis dan Empati Siswa terhadap Lingkungan. Journal of Educational Research and Evaluation, 1 (2) 133138.

Sanjaya, Wina, 2006. Strategi Pembelajaran Berorientasi Standar Proses Pendidikan. Kencana Prenada Media, Jakarta.

Santrock, John W., 2007. Perkembangan Anak. Erlangga, Jakarta.

Syahbana, Ali. 2012. Peningkatan Kemampuan Berpikir Kritis Matematis Siswa SMP melalui Pendekatan Contextual Teaching And Learning: Edumatica, 02 (01) 45-57. 